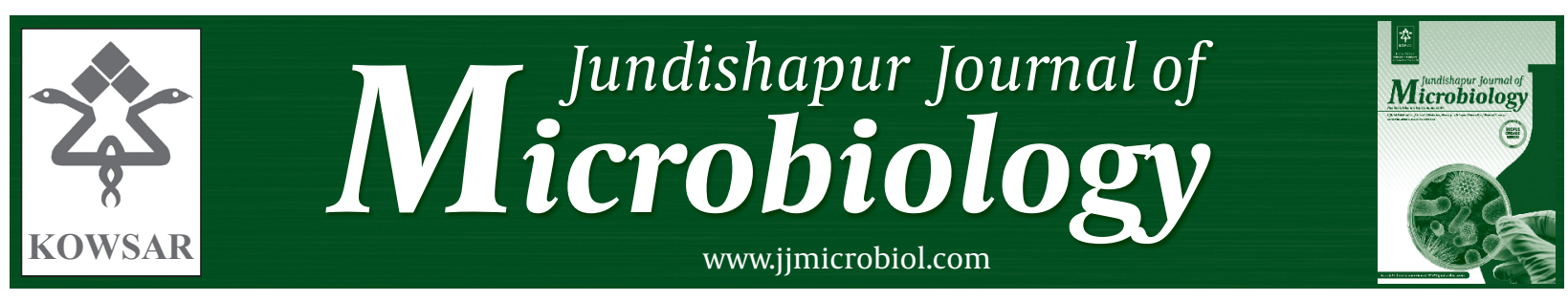

\title{
Evaluating the Prevalence of Toxoplasma gondii in Meat and Meat Products in Ahvaz by PCR Method
}

\author{
Mahmoud Rahdar ${ }^{1}$, Ali Reza Samarbaf-Zadeh ${ }^{2}$, Leila Arab ${ }^{2 *}$ \\ ${ }^{1}$ Department of Parasitology, Faculty of Medicine, Ahvaz Jundishapur University of Medical Sciences, Ahvaz, IR Iran \\ 2 Department of Virology, Faculty of Medicine, Ahvaz Jundishapur University of Medical Sciences, Ahvaz, IR Iran
}

\section{A R T I C L E I N F O}

\section{Article type:}

Original Article

\section{Article history:}

Received: 28 Jan 2011

Revised: 27 Feb 2012

Accepted: 05 Mar 2012

\section{Keywords:}

Meat

Meat Products

Toxoplasma

Polymerase Chain Reaction

\begin{abstract}
A B S T R A C T
Background: Toxoplasma gondii is an obligate, intracellular parasite, which is widely spread in the world. The parasite is able to infect all warm-blooded hosts including human. The infection occures via consumption of food or water containing oocytes, eating undercooked meats containing tissue cysts, and placenta. Undercooked meat consumption is one of the most important ways of Toxoplasma transmission especially in pregnancy period. Raw and undercooked meats have been reported responsible for $50 \%$ of congenital toxoplasmosis.

Objectives: The current study was conducted to determine the prevalence of T. gondii in lamb and beef, and also meat products by molecular method in Ahvaz,southwest of Iran. Materials and Methods: Totally 190 samples were collected from local retailers in Ahvaz city. Samples of tongue, heart and muscle were taken from 50 lamb and 50 beef distributors and 90 meat product samples (sausages, hamburgers and salami, 30 samples of each). Collected samples were minced by electric meat grinder. DNA was extracted from 190 meat and meat product samples by Qiagen DNA Mini Kit. specific primers for the $T$. gondii B1 gene was used to detect the parasite in samples, by PCR method.

Results: A total of seven lamb out of 50 (14\%) and two beef out of $50(4 \%)$ were found as positive for T. gondii cyst. The parasite was not isolated from any of the meat product samples. Conclusions: The detection of the parasite in slaughtered animals, indicated that the risk still exists for food-transmitted toxoplasmosis, and consumption of raw or undercooked meat can transmit the infection to human community.
\end{abstract}

Published by Kowsar Corp, 2012. cc 3.0.

Implication for health policy/practice/research/medical education:

According to the presence of T. gondii DNA in meat, the potential risk of the transmission of the disease through T. gondii containing meat should still be considered a public health threat. So it is suggested that not only pregnant women should be addressed but the whole population should be informed how to prevent infection.

Please cite this paper as:

Rahdar M, Samarbaf-Zadeh AR, Arab L. Evaluating the Prevalence of Toxoplasma gondii in Meat and Meat Products in Ahvaz by PCR Method. Jundishapur J Microbiol. 2012;5(4):570-3. DOI: 10.5812/jjm.4280

\footnotetext{
* Corresponding author: Leila Arab, Department of Parasitology Medical Faculty, Ahvaz Jundishapur University of Medical Sciences, Ahvaz, IR Iran. Tel: +989166524492, Fax: +98-6113332036, E-mail: larab128@yahoo.com

DOI: $10.5812 / j \mathrm{jm} .4280$

(C) 2012 Ahvaz Jundishapur University of Medical Sciences; Published by Kowsar Corp.

This is an Open Access article distributed under the terms of the Creative Commons Attribution License (http://creativecommons.org/licenses/by/3.0), which permits unrestricted use, distribution, and reproduction in any medium, provided the original work is properly cited.
} 


\section{Background}

Toxoplasma gondii is an obligate, intracellular parasite which is widely spread in the world (1). Toxoplasmosis is listed as the third-biggest cause of life-threatening food-borne infections (2). The parasite is able to infect all warm-blooded hosts such as human. The infection has various clinical symptoms in immunocompetent or immunocompromised patients and pregnant women. T. gondii has three ways of transmission: 1 ) consuming food or water containing oocytes, 2) eating undercooked meats containing tissue cysts, and 3) transmission via placenta (1). Consumption of undercooked meat is one of the most important ways (28\%) of transmission among pregnant toxoplasmosis patients (3) and has been regarded as the most significant risk factor of primary infection during pregnancy (4-7).

T. gondii prevalence in Iran is said to be up to $50 \%$ which increases from dry to humid provinces in north of Iran (8). It has been reported that up to $63 \%$ of seroconversion during pregnancy happens after undercooked or raw meat consumption (6). In Norway, raw or undercooked meat consumption has been reported as the major risk factor for toxoplasmosis in pregnant women (7) and has also been responsible for $50 \%$ of congenital toxoplasmosis (9). Serological surveys indicat that Toxoplasma infection exists largly among animals used for meat production, such as pigs, sheep, and goats (10). High seropositivity scores $(26.6 \%-88.7 \%$ ) for $T$. gondii have been reported in slaughtered animals (11,12). These meats all fall into the risk profile category of red meat and apart from chicken and birds. While raw meats have been most commonly implicated, cured meats such as ham have also been found to contain T. gondii cysts occasionally (13). T. gondii was isolated from only one of 40 swine sausage samples commercialized in the city of Erechim-RS (Brazil) (14). An explanation for difficulty to isolate the agent is salt (in a $3 \%$ concentration) which inactivates the parasite for at least three days (14).

\section{Objectives}

This study was conducted to determine T.gondii prevalence in slaughtered animals and meat products in Ahvaz using molecular methods. There were no molecular study on meat and meat products in this Province.

\section{Materials and Methods}

\subsection{Sample Collection}

The samples were collected from abattoirs and retailers in Ahvaz city, including: 100 lamb and beef samples (50 samples each type) were collected from tongue, heart and muscles, and 90 meat product samples (sausages, hamburgers and salami) each one 30 samples. A 50 gram meat sample was cut. Knives were thoroughly rinsed with hot water and soap to prevent cross-contamination.
The sample tissues were stored at $-20^{\circ} \mathrm{C}$ until used.

\subsection{DNA Extraction}

The samples were minced by an electric meat grinder and $25-30 \mathrm{mg}$ of each minced tissue was used following the manufacturer's instructions of a commercial DNA extraction kit (Qiagen,Valencia, CA, USA) the samples were resuspended in $180 \mu \mathrm{L}$ ATL buffer and $20 \mu \mathrm{L}$ proteinase $\mathrm{K}$ (supplied in the QIAamp DNA Mini Kit), and the protocol recommended for tissue samples was followed. All DNA extracts were stored at $-20^{\circ} \mathrm{C}$ until used. This product was used as a template for PCR.

\subsection{PCR Amplification}

B1 gene was selected for PCR because of being highly conserved among Toxoplasma strains with 35-fold repeat gene and 2214 nucleotides in each repeat. This gene was targeted to generate specific primers Tg1, Tg2 and amplified 469-bp DNA fragment of the B1 gene (15). The positive control was obtained from Parasitology department of Shiraz University of Medical Sciences. Primers Tg1 (5'AAAAATGTGGGAATGAAAGAG 3') and Tg2 (5'ACGAATCAACGGAACTGTAAT 3') were used for PCR amplification (15).The PCR mixture contained $1 \mu \mathrm{M}$ of each primer (Tg1 and Tg2), $5 \mathrm{mM}$ of $10 \times$ PCR Gold buffer, $1.5 \mathrm{mM}$ of $\mathrm{MgCl} 2$, $1 \mathrm{mM}$ of deoxynucleoside triphosphate (CinnaGen), 0.3 U of Taq DNA polymerase (CinnaGen) and $20.2 \mu \mathrm{l}$ D.W. The reaction volume was $50 \mu \mathrm{l}$ containing $20 \mu \mathrm{l}$ of DNA extracts. Reactions were preheated in thermal cycler (Bio Rad-USA) for $10 \mathrm{~min}$ at $95^{\circ} \mathrm{C}$, followed by 35 cycles of $94^{\circ} \mathrm{C}$ for $1 \mathrm{~min}, 52^{\circ} \mathrm{C}$ for $30 \mathrm{~s}$ and $72^{\circ} \mathrm{C}$ for $1 \mathrm{~min}$, with a final extension step at $72^{\circ} \mathrm{C}$ for $7 \mathrm{~min}(15) .10 \mu \mathrm{l}$ of amplified products were run in $1 \%$ agarose gel. Two control samples were

Figure. Result of PCR Analysis of the B1 Gene From T. gondii-Infected Samples

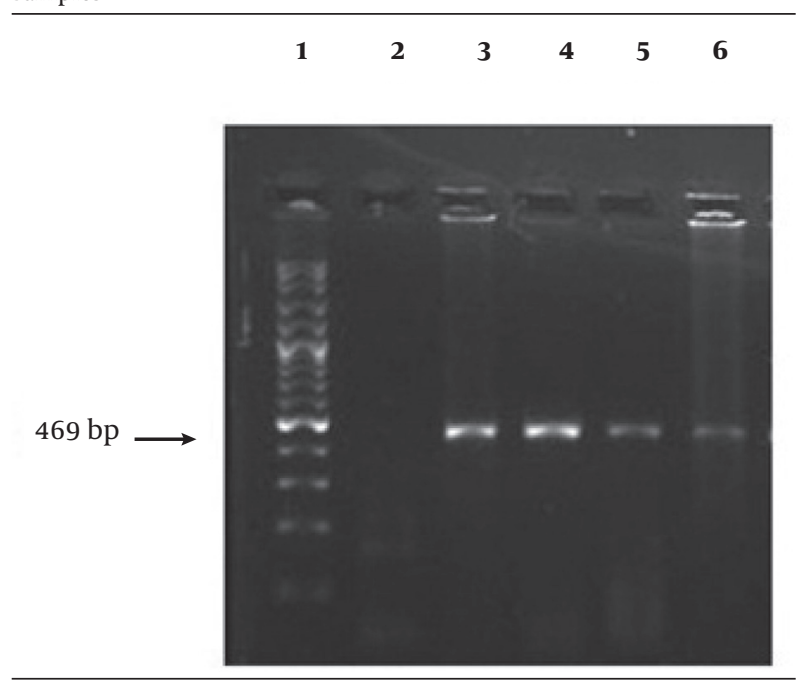

1: Marker (100 bp), 2: Negative control, 3: Positive control, 4,5,6: Positive specimens. 
used for each PCR cycle including T. gondii DNA as positive and distilled water as negative control.

\section{Results}

A total of seven lamb out of 50 (14\%) and two beef out of $50(4 \%)$ were found as positive for T. gondii. The parasite was not isolated from any of the meat product samples. Total positivity rate was $4.7 \%$ in 190 samples. The results of PCR are indicated in Figure 1.

\section{Discussion}

Toxoplasma infects cover a large variety of hosts including human, animals and birds. In this study, seven lambs out of $50(14 \%)$ were found positive for T. gondii. Asgari et al. presented the total prevalence Toxoplasma infection as $33.3 \%$ among 22 goats $(22.7 \%$ ) and 56 sheep (37.5\%) by PCR (16). It has been assumed that infected sheep, will remain persistently infected for their whole life (17). Ghorbani et $a l$. have reported the Serological prevalence of toxoplasmosis in sheep in Kuzestan (southwest of Iran), Mazandaran and Gilan (Notrh of Iran) were $12.6 \%$, 32.5-35.8 \% and $29-31 \%$ respectively (18). Sharif et al. found $30 \%, 35 \%$ sero-positivity in goats and sheep respectively by IFA test from Mazandaran Province (19). These different results indicate that animals were exposed to different environmental contamination with T. gondii oocytes.

In this study $4 \%$ of cattle were found positive for T. gondii and the infection was more frequent in sheep compared with cattle which was similar to other studies. In serological study, antibodies against $T$. gondii were found in goats, sheep, cattle, $23.7 \%, 22.5 \%$ and $4.8 \%$, respectively (20). Dubey and Thulliez have reported that the Toxoplasma infection in cattle dose not usually cause clinical symptoms because of high natural resistance to the parasite (21). Aspinall detected by PCR, 19 positive out of 57 samples of pork, six out of nine lamb, and one out of four beef (22). In our study the parasite was not isolated from any of the meat product samples. These results indicate that meat products probably have low importance as a source of infection for human toxoplasmosis in the studied region.

Warnekulasuriya detected one positive sample out of 67 cured meat samples, including dried and semi-dried sausages and hams using PCR in UK. The author suggested that the detected level of parasite contamination would be sufficient to establish human infection following the consumption of a typical meal portion of cured meat (13). Prevalence of Toxoplasma infection indicated that from 164 meat product samples including salami, sausages, hamburgers, and kebab samples were $16.6 \%, 19.1 \%, 15$ and $56.6 \%$ respectively, in Tabriz (23). In this study primers specific for T. gondii SAG2 locus was used to detect the parasite in samples. In Falah study, samples (sausages, hamburgers) have been picked from the factories in Tabriz province. Despite the dramatic differences in pollution levels in different areas of Iran due to different weather conditions, especially favorable temperature for the maintenance of parasite oocytes, it seems that high pollution in Fallah study is justifiable. Besides, beef supplies are used more in the preparation of these products and based on studies in Iran and the world, contamination of cattle is much lower than sheep. Da silva reported that $T$. gondii DNA was found in $27.14 \%$ of 70 sausage samples examined in Brazil (24).T. gondii was isolated from only one of 40 swine sausage samples in Brazil (14). Among food animals, pigs are considered to be the major source of $T$. gondii for humans, so probably one reason for different results, in different regions, could be using meat products that contain pork meat (25). These findings may be related to various ways of infection prevalence in meatproducing animals, or different eating habits; it has alsobeen indicated that $T$. gondii is killed by many of the salting, curing, freezing, or heating procedures that are used in meat processing, these products are not a likely source of human exposure to the infection. It is difficult to find $T$. gondii tissue cysts in large animal species for several reasons, including sampling bias and preferred parasite sites. Dubey has estimated that less than 1 tissue cyst $/ 50 \mathrm{~g}$ of tissue is likely to be found in T. gondii-infected pigs (26). Thus, it is possible that when performing any test for tissue cyst detection, false-negatives can result from insufficient sample size or improper sample acquisition. Therefore in this study 50 gram of meat from different parts of carcass and meat products was selected to increase the chance of finding parasite in the samples. Overall, a low prevalence of $T$. gondii was found in meat and meat products in Khuzestan.

The results of this study confirm existence of T. gondii in slaughtered animals. Although the infection risk in lamb is greater than beef, but beef also has remarkable importance regarding the transmission of T.gondii to humans. Therefore, the potential risk of the disease transmission by consumption of contaminated meat should still be considered as a public health problem. Based on the obtained results, it is suggested that not only pregnant women and immunocompromised patients should be addressed but also the whole population should be informed on how to prevent infection.

\section{Acknowledgements}

This study was technically supported by the Tropical and Infectious diseases Researches Center of Ahvaz Jundishapur University of Medical Sciences. We are grateful for the sincere collaboration of the staff members of this center and especially thanks to Dr. Asgari for providing the positive control of T.gondii.

\section{Financial Disclosure}

None Declared. 


\section{Funding Support}

This research was financially supported by Ahvaz Jundishapur University of Medical Sciences.

\section{References}

1. Despommier DD, Gwadz RW, Hotez PJ, Knirsch CA. Toxoplasma gondii. In: Despommier DD, editor. Parasitic diseases, New York: Apple Trees Productions; 2000.

2. Kravetz JD, Federman DG. Toxoplasmosis in pregnancy. Am J Med. 2005;118 (3):212-6.

3. Kravetz JD, Federman DG. Prevention of toxoplasmosis in pregnancy: knowledge of risk factors. Infect Dis Obstet Gynecol. 2005;13 (3):161-5.

4. Baril L, Ancelle T, Goulet V, Thulliez P, Tirard-Fleury V, Carme B. Risk factors for Toxoplasma infection in pregnancy: a case-control study in France. Scand J Infect Dis. 1999;31 (3):305-9.

5. Bobic B, Jevremovic I, Marinkovic J, Sibalic D, Djurkovic-Djakovic O. Risk factors for Toxoplasma infection in a reproductive age female population in the area of Belgrade, Yugoslavia. Eur J Epidemiol.1998;14 (6):605-10.

6. Cook AJ, Gilbert RE, Buffolano W, Zufferey J, Petersen E, Jenum PA, et al. Sources of toxoplasma infection in pregnant women: European multicentre case-control study. European Research Network on Congenital Toxoplasmosis. BMJ. 2000;321 (7254):142-7.

7. Kapperud G, Jenum PA, Stray-Pedersen B, Melby KK, Eskild A, Eng J. Risk factors for Toxoplasma gondii infection in pregnancy. Results of a prospective case-control study in Norway. Am J Epidemiol.1996;144 (4):405-12.

8. Assmar M, Amirkhani A, Piazak N, Hovanesian A, Kooloobandi A, Etessami R. [Toxoplasmosis in Iran. Results of a seroepidemiological study]. Bull Soc Pathol Exot. 1997;90 (1):19-21.

9. Cook A, Gilbert R, Buffolano W, Zufferey J, Petersen E, Jenum P. Eating undercooked meat contributed to approximately $50 \%$ of cases of acute toxoplasma infection in pregnancy. Evid Based $\mathrm{Ob}$ stetrics Gynecol. 2001;3 (2).

10. Tenter AM, Heckeroth AR, Weiss LM. Toxoplasma gondii: from animals to humans. Int J Parasitol. 2000;30 (12-13):1217-58.

11. Babür C, Inci A, Karaer Z. Detection on seropositivity of Toxoplasma gondii in sheep and goats in around of Cankiri using SabinFeldman dye test. Tü rkiye Parazitoloji Dergisi. 1997;21:409-12.

12. Babur C, Karaer Z. Isolation and seroincidence studies of Toxoplasma gondii infection in sheep. Acta Parasitologica Turcica.
1997;21:293-9.

13. Warnekulasuriya MR, Johnson JD, Holliman RE. Detection of Toxoplasma gondii in cured meats. Int J Food Microbiol. 1998;45 (3):211-5.

14. De oliveira mendonça A, Domingues PF, Vieira da silva A, Bergamaschi pezerico S, Langoni $\mathrm{H}$. Detection of Toxoplasma gondii in swine sausages. Parasitología latinoamericana. 2004;59 (1-2):42-5.

15. Jalal S, Nord CE, Lappalainen M, Evengard B. Rapid and sensitive diagnosis of Toxoplasma gondii infections by PCR. Clin Microbiol Infect. 2004;10 (10):937-9.

16. Asgari Q, Sarnevesht J, Kalantari M, Sadat SJ, Motazedian MH, Sarkari B. Molecular survey of Toxoplasma infection in sheep and goat from Fars province, Southern Iran. Trop Anim Health Prod. 2011;43 (2):389-92.

17. Uggla A, Buxton D. Immune responses against Toxoplasma and Sarcocystis infections in ruminants: diagnosis and prospects for vaccination. Rev Sci Tech. 1990;9 (2):441-62.

18. Ghorbani M, Hafizi A, Shegerfcar MT, Rezaian M, Nadim A, Anwar M, et al. Animal toxoplasmosis in Iran. J Trop Med Hyg. 1983;86 (2):73-6.

19. Sharif M, Gholami S, Ziaei H, Daryani A, Laktarashi B, Ziapour SP, et al. Seroprevalence of Toxoplasma gondii in cattle, sheep and goats slaughtered for food in Mazandaran province, Iran, during 2005. Vet J. 2007;174 (2):422-4.

20. Hamzavi Y, Mostafaie A, Nomanpour B. Serological prevalence of toxoplasmosis in meat producing animals. Iranian J Parasitol. 2007;2 (1).

21. Dubey JP, Thulliez P. Persistence of tissue cysts in edible tissues of cattle fed Toxoplasma gondii oocysts. Am J Vet Res. 1993;54 (2):270-3.

22. Aspinall TV, Marlee D, Hyde JE, Sims PF. Prevalence of Toxoplasma gondii in commercial meat products as monitored by polymerase chain reaction--food for thought? Int J Parasitol. 2002;32 (9):1193-9.

23. Fallah E, Hajizadeh M, Farajnia S, Khanmahammadi M. SAG2 locus genotyping of Toxoplasma gondii in meat products of East Azerbaijan Province, North West of Iran During 2010-2011. Afr J Biotechnol. 2011;10 (62):13631-5.

24. Vieira Da Silva A, De Oliveira Mendonça A, Bergamaschi Pezerico $\mathrm{S}$, Domingues PF, Langoni H. Genotyping of Toxoplasma gondii strains detected in pork sausage. Parasitología latinoamericana. 2005;60 (1-2):65-8.

25. Dubey JP. Toxoplasmosis. J Am Vet Med Assoc. 1994;205 (11):1593-8.

26. Dubey JP, Lunney JK, Shen SK, Kwok OC, Ashford DA, Thulliez P. Infectivity of low numbers of Toxoplasma gondii oocysts to pigs. J Parasitol. 1996;82 (3):438-43. 